\title{
Evaluation of Air Quality Impacts from Addition of Boiler 5 at Naval Reactors Facility
}

\author{
A Jeffrey Sondrup
}

October 2018

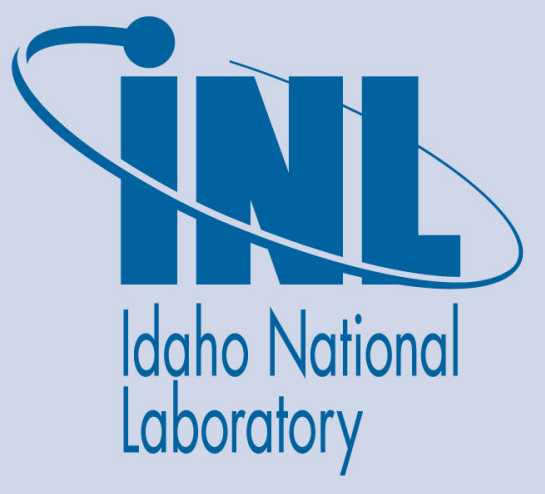

The INL is a U.S. Department of Energy National Laboratory operated by Battelle Energy Alliance 


\title{
Evaluation of Air Quality Impacts from Addition of Boiler 5 at Naval Reactors Facility
}

\author{
A Jeffrey Sondrup
}

October 2018

Idaho National Laboratory Idaho Falls, Idaho 83415

http://www.inl.gov

Prepared for the U.S. Department of Energy Office of Nuclear Energy Under DOE Idaho Operations Office Contract 7018836 
Rev. 08

Title: $\quad$ Evaluation of Air Quality Impacts from Addition of Boiler 5 at Naval Reactors Facility

$\begin{array}{lllll}\text { ECAR No.: } 4264 & \text { Rev. No.: } 1 & \text { Project No.: } & \text { N/A } & \text { Date: } 10 / 16 / 2018\end{array}$

\begin{tabular}{|c|c|c|}
\hline $\begin{array}{l}\text { Does this ECAR involve } \\
\text { a Safety SSC? }\end{array}$ & N/A & Professional Engineer's Stamp \\
\hline $\begin{array}{l}\text { Safety SSC } \\
\text { 2. Determination Document } \\
\text { ID }\end{array}$ & $\mathrm{N} / \mathrm{A}$ & PE Stamp Not Required per LWP-10010 \\
\hline 3. Engineering Job (EJ) No. & $N / A$ & \\
\hline 4. SSC ID & $\mathrm{N} / \mathrm{A}$ & \\
\hline 5. Building & N/A & \\
\hline 6. Site Area & Naval Reactors Facility & \\
\hline
\end{tabular}

7. Objective/Purpose:

This report documents an air-quality impact analysis of criteria air-pollutant emissions from the addition of Boiler 5 at NRF to support the permit application. Maximum increases in criteria airpollutant concentrations resulting from Boiler 5 emissions were modeled and compared to significant contribution levels, as defined in IDAPA 58.01.01. Concentrations were calculated at each of 1352 potential public receptor locations on and around the INL Site, and reported at 1) receptor locations where the maximum concentrations occurred as a result of operating only Boiler 5, and 2) receptor locations where the maximum concentrations occurred as a result of baseline actual emissions (BAEs) from all significant INL sources considered in the INL Application for a Synthetic Minor Sitewide Air Quality Permit to Construct with Facility Emission Cap Component (DOE-ID 2017).

8. If revision, please state the reason and list sections and/or pages being affected:

NA.

9. Conclusions/Recommendations

Increases in criteria air pollutant concentrations resulting from operation of NRF Boiler 5 are considerably less than significant contribution levels at all INL public receptor locations. 
Rev. 08

Title: $\quad$ Evaluation of Air Quality Impacts from Addition of Boiler 5 at Naval Reactors Facility

$\begin{array}{lllll}\text { ECAR No.: } 4264 & \text { Rev. No.: } 1 & \text { Project No.: } & \text { N/A } & \text { Date: } 10 / 16 / 2018\end{array}$

\section{CONTENTS}

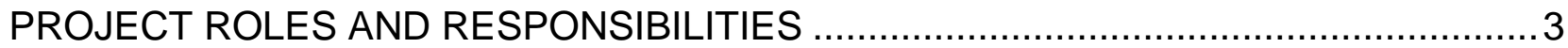

SCOPE AND BRIEF DESCRIPTION

DESIGN OR TECHNICAL PARAMETER INPUT AND SOURCES …......................... 4

RESULTS OF LITERATURE SEARCHES AND OTHER BACKGROUND DATA ............ 4

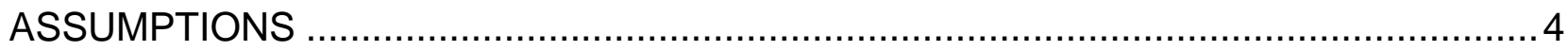

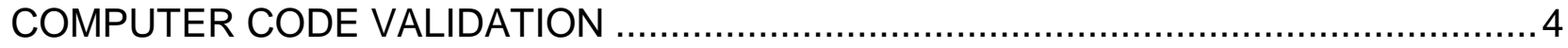

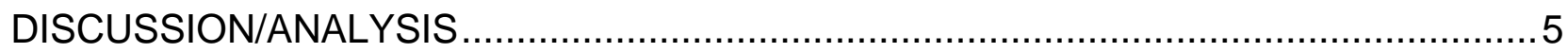

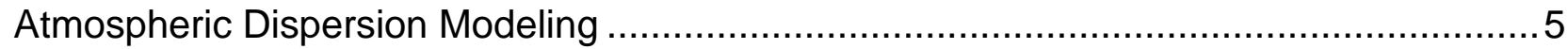

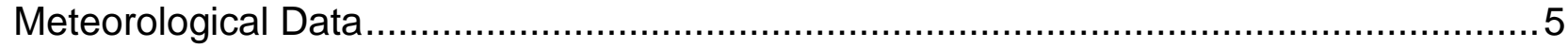

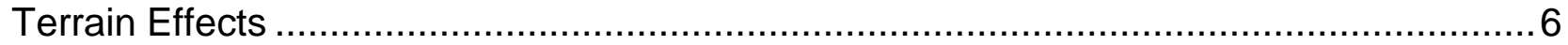

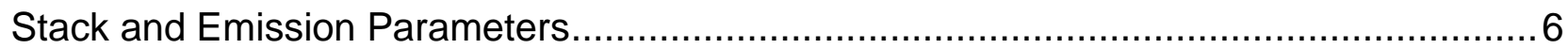

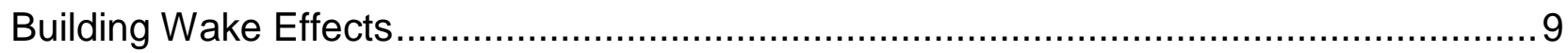

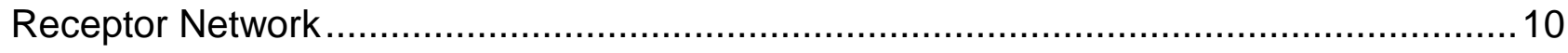

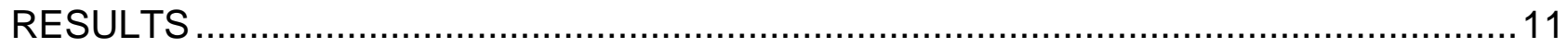

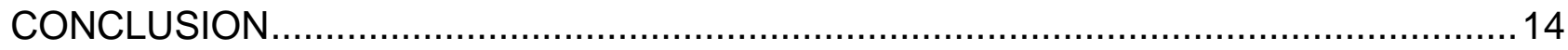

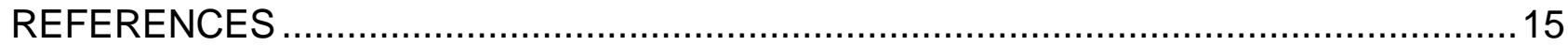

APPENDIXES

Appendix A - Perl Script for Post-processing AERMOD Results 
Rev. 08

Title: $\quad$ Evaluation of Air Quality Impacts from Addition of Boiler 5 at Naval Reactors Facility

ECAR No.: 4264 Rev. No.: 1

Project No.:

N/A

Date: $10 / 16 / 2018$

\section{PROJECT ROLES AND RESPONSIBILITIES}

\begin{tabular}{|c|c|c|c|}
\hline Project Role & Name (Typed) & Organization & Pages covered (if applicable) \\
\hline Performer & A. Jeffrey Sondrup & B360 & eCR 663679 \\
\hline Checker $^{\mathrm{a}}$ & Mark A. Verdoorn & H530 & eCR 663679 \\
\hline Independent Reviewer ${ }^{b}$ & Tim Solle & H510 & eCR 663679 \\
\hline CUI Reviewer ${ }^{c}$ & $\mathrm{~N} / \mathrm{A}$ & $\mathrm{N} / \mathrm{A}$ & \\
\hline Manager ${ }^{d}$ & Chris T. Wright & B360 & eCR 663679 \\
\hline Requestore & James I. Laner & NRF & eCR 663679 \\
\hline Nuclear Safetye & $\mathrm{N} / \mathrm{A}$ & $\mathrm{N} / \mathrm{A}$ & \\
\hline Document Owner & A. Jeffrey Sondrup & B360 & eCR 663679 \\
\hline
\end{tabular}
a. Confirmation of completeness, mathematical accuracy, and correctness of data and appropriateness of assumptions.
b. Concurrence of method or approach. See definition, LWP-10106.
c. Concurrence with the document's markings in accordance with LWP-11202.
d. Concurrence of procedure compliance. Concurrence with method/approach and conclusion.
e. Concurrence with the document's assumptions and input information. See definition of Acceptance, LWP-10200. 
Rev. 08

Title: $\quad$ Evaluation of Air Quality Impacts from Addition of Boiler 5 at Naval Reactors Facility

$\begin{array}{lllll}\text { ECAR No.: } 4264 & \text { Rev. No.: } 1 & \text { Project No.: } & \text { N/A } & \text { Date: } 10 / 16 / 2018\end{array}$

\section{SCOPE AND BRIEF DESCRIPTION}

NRF proposes to add a new boiler to the sources covered by the Synthetic Minor Sitewide Air Quality Permit to Construct with Facility Emission Cap Component (DOE-ID 2017). NRF Boiler 5 was installed in 2017 and first fired in early 2018 under a permit to construct exemption determination. This report documents an air-quality impact analysis of criteria air-pollutant (CAP) emissions from the addition of Boiler 5 at NRF to show that the boiler emissions meet the criteria for adding sources to the sitewide permit.

Atmospheric dispersion modeling of Boiler 5 emissions was performed using the same computer code and model parameters used to support the INL Application for a Synthetic Minor Sitewide Air Quality Permit to Construct with Facility Emission Cap Component (DOE-ID 2017), hereafter referred to as the INL Sitewide permit application. The modeling that supports the permit application is documented in Sondrup (2015).

Maximum increases in CAP concentrations resulting from Boiler 5 emissions were modeled and compared to significant contribution levels (SCLs) defined in IDAPA 58.01.01.006.109. Concentrations were calculated at each of 1352 potential public receptor locations on and around the INL Site, and reported at 1) receptor locations where the maximum concentrations occurred as a result of operating only Boiler 5, and 2) receptor locations where the maximum concentrations occurred as a result of baseline actual emissions (BAEs) from all significant INL sources considered in the INL Sitewide permit application (DOE-ID 2017). These sources include primarily boilers, emergency generators, certain mobile equipment, and emissions from waste-retrieval and treatment operations.

\section{DESIGN OR TECHNICAL PARAMETER INPUT AND SOURCES}

Input data and sources are provided in the Discussion/Analysis section.

\section{RESULTS OF LITERATURE SEARCHES AND OTHER BACKGROUND DATA}

See Discussion/Analysis Section and References Section.

\section{ASSUMPTIONS}

See Discussion/Analysis Section.

\section{COMPUTER CODE VALIDATION}

All computer modeling was performed with the EPA-approved AERMOD dispersion-modeling system (Version 14134) (EPA 2004a). The meteorological data set was produced with the companion AERMET model (Version 14134) (EPA 2004b) using surface data from the Idaho Falls airport, and upper-air data from Boise International Airport supplied by Idaho Department of Environmental Quality (DEQ). Onsite meteorological data from the Grid 3 Mesonet tower located near the center of INL (north of INTEC) and supplied by the local National Oceanic and Atmospheric Administration (NOAA) office was used for surface wind directions and wind speeds. Surface data (i.e., land use data that define roughness, albedo, Bowen ratio, and other parameters) were processed using the AERSURFACE utility (Version 13016) (EPA 2013). 
Rev. 08

Title: $\quad$ Evaluation of Air Quality Impacts from Addition of Boiler 5 at Naval Reactors Facility

$\begin{array}{lllll}\text { ECAR No.: } 4264 & \text { Rev. No.: } 1 & \text { Project No.: N/A } & \text { Date: } 10 / 16 / 2018\end{array}$

Building wake-effect parameters for the Boiler 5 stack were determined with the EPA Building Profile Input Program with Plume Rise Enhancement (BPIP-PRIME) (EPA 2004c), Version 04274, designed for use with the AERMOD model. BPIP-PRIME was run under the BEEST for Windows platform (BEELine Software, Version 9.95).

A Perl script (aermodpp.pl) was used to post-process the pollutant-concentration output files generated by AERMOD using the PLOTFILE command. The script extracts concentrations for each averaging period and writes the results to a text file that was imported into a spreadsheet. This script is included as Appendix A.

Microsoft Excel 2013 (15.0.5041.1000) MSO (15.0.5031.1000) 32 bit, part of Microsoft Office Professional Plus 2013, was used for supporting calculations. Cell formulas were checked for accuracy, and a sample of the calculations was checked by hand. All formula cells have been locked for editing and password protected.

Except for a few modifications, the models and modeling methodology performed is the same as was performed for the INL Sitewide permit application (DOE-ID 2017). The INL Sitewide permit modeling (Sondrup 2015) and the protocol document for conducting the modeling (Sondrup and Verdoorn 2015) were reviewed extensively and approved by Idaho DEQ personnel for purposes of issuing the permit.

All electronic files, including computer code input, output, and spreadsheet files are contained in a zip file that can be accessed by selecting "Additional Information" (select Native File) in the INL Electronic Document Management System.

\section{DISCUSSIONIANALYSIS}

\section{Atmospheric Dispersion Modeling}

The atmospheric dispersion modeling is based on the methodology used for the INL Sitewide permit application (DOE-ID 2017). The same base AERMOD input files were used with some modifications and the same meteorological data files were used. The modifications are described in this section with a basic description of the modeling methodology. For a complete description of the modeling methodology, see Sondrup (2015).

\section{Meteorological Data}

Five years of onsite meteorological data (2000 to 2004) from the INL Site Grid 3 Mesonet tower was provided by R. Eckman of the Idaho Falls' NOAA office in five files (GRI2000.MET, GRI2001.MET, GRI2002.MET, GRI2003.MET and GRI2004.MET). The Grid 3 Mesonet tower is the most central tower to all INL facilities and located only $6.3 \mathrm{~km}$ from NRF. The data include delta temperature $\left({ }^{\circ} \mathrm{C}\right)$, precipitation amount $(\mathrm{cm})$, insolation (total amount of solar radiation energy received per unit area measured in watts $\left./ \mathrm{m}^{2}\right)$, pressure (millibars $\left.\times 10\right)$, measurement height $(\mathrm{m})$, wind speed $(\mathrm{m} / \mathrm{s})$, wind direction (degrees), temperature $\left({ }^{\circ} \mathrm{C}\right)$, and standard deviation of the horizontal wind angle. These data were converted to the AERMET units and wind speed measured at the $15 \mathrm{~m}$ height was extrapolated to $10 \mathrm{~m}$ by NOAA and read into AERMET (Version 14134).

Surface data from the Idaho Falls Airport was obtained from the National Climatic Data Center (http://www1.ncdc.noaa.gov/pub/data/noaa/) in TD-3503 (ISH) format, which is read directly by AERMET. Upper air data from the Boise International Airport in the FSL format were provided by Idaho 
Rev. 08

Title: $\quad$ Evaluation of Air Quality Impacts from Addition of Boiler 5 at Naval Reactors Facility

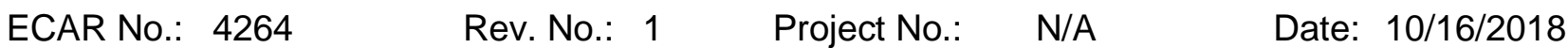

DEQ and were used without modification. The onsite, surface, and upper air data files were processed with AERMET (Version 14134) to provide a 5-year surface-data file (grd35yr.sfc) and upper-air-data file (grd35yr.pfl) for running AERMOD.

\section{Terrain Effects}

Terrain data for AERMOD were processed using the AERMAP pre-processor. The processed data consists of terrain elevation and hill heights for each defined receptor. These data were generated by Idaho DEQ modeling staff using AERMAP (Version 11103) and provided to INL in the file AERMAP723.rcf for the 1,352 public receptor locations. Receptor locations are defined in UTM coordinates (Zone 12) based on datum NAD 83. The terrain data were extracted from 1 arc-second seamless National Elevation Database files covering the area between -112.005 and -113.644 degrees longitude and 42.967 and 44.287 degrees north latitude. All coordinates and elevations are in meters. The provided file AERMAP723.rcf is a text file written in AERMOD input format and was used in each AERMOD input file.

Land surface data (e.g., roughness height, albedo, and terrain) were processed for the Grid 3 Mesonet station using the AERSURFACE utility (Version 13016) (EPA 2013) and National Land Cover Data file, idaho_NLCD92.tif. The National Land Cover Data are derived from the early to mid-1990s Landsat Thematic Mapper satellite data and have a 21-class land-cover classification scheme applied consistently over the United States. The spatial resolution of the data is $30 \mathrm{~m}$ and mapped in the Albers Conic Equal Area projection, NAD 83. The National Land Cover Data are provided on a state-by-state basis in the website http://www.webgis.com/nlcd92.html.

\section{Stack and Emission Parameters}

Figure 1 shows the approximate Boiler 5 stack location. The stack parameters for Boiler 5 were provided by NRF (R. Brown email to A.J. Sondrup, October 10, 2017) and shown in Table 1. 
TEM-10200-1

Rev. 08

Title: $\quad$ Evaluation of Air Quality Impacts from Addition of Boiler 5 at Naval Reactors Facility

$\begin{array}{lllll}\text { ECAR No.: } 4264 & \text { Rev. No.: } 1 & \text { Project No.: } & \text { N/A } & \text { Date: } 10 / 16 / 2018\end{array}$

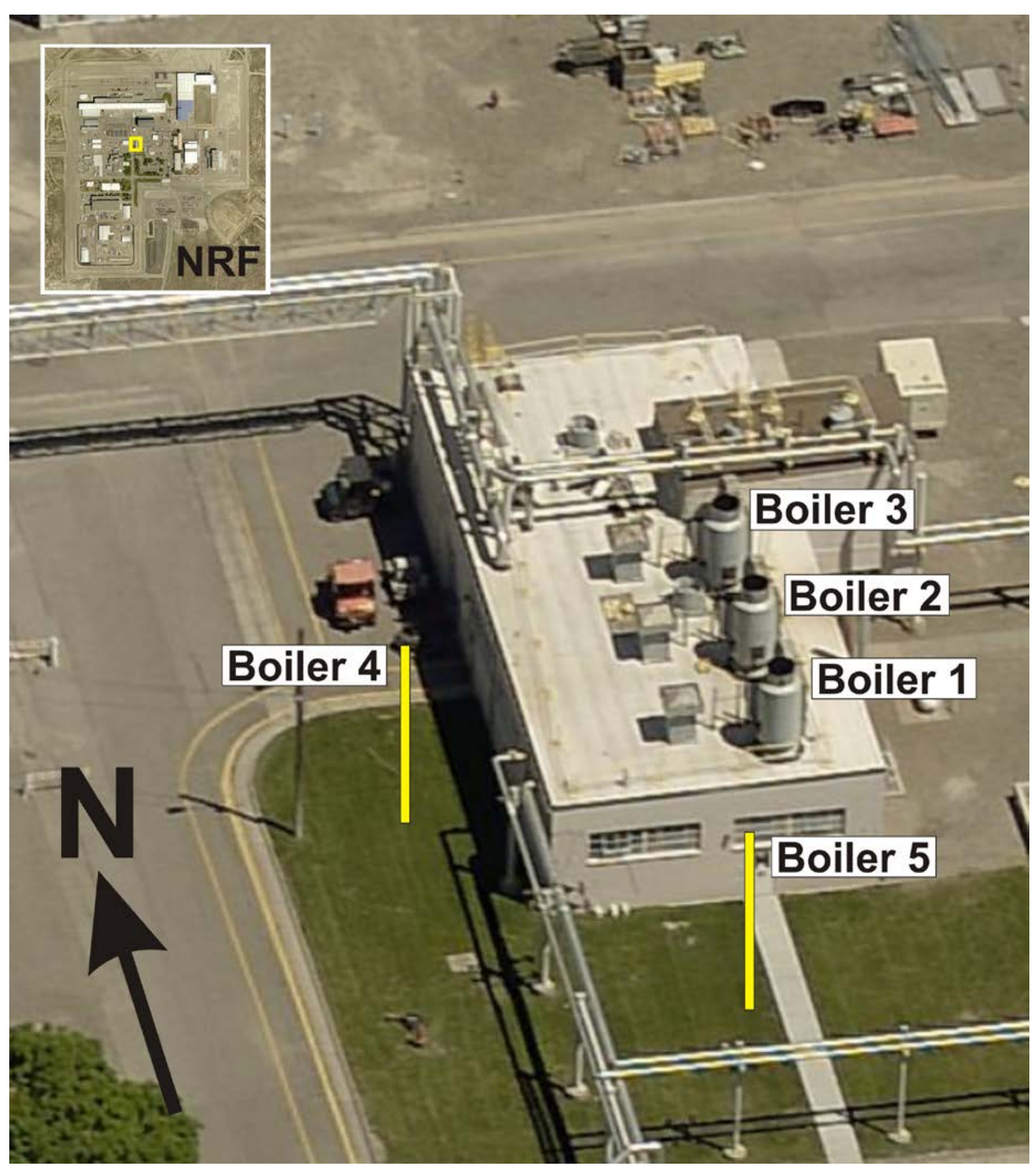

Figure 1. Location of NRF Boiler stacks 1-3 and approximate location of Boiler stacks 4 and 5. The area shown in the photo is indicated by the yellow highlighted area in the facility map inset (upper left). 
Rev. 08

Title: $\quad$ Evaluation of Air Quality Impacts from Addition of Boiler 5 at Naval Reactors Facility

ECAR No.: 4264

Rev. No.: 1

Project No.:

N/A

Date: $10 / 16 / 2018$

Table 1. Boiler 5 stack parameters.

\begin{tabular}{lc}
\multicolumn{1}{c}{ Stack Parameter } & Value \\
\hline UTM Easting (datum NAD 83) & $345,438 \mathrm{~m}$ \\
UTM Northing (datum NAD 83) & $4,834,667 \mathrm{~m}$ \\
Base Elevation & $1,479 \mathrm{~m}$ \\
Height & $6.81 \mathrm{~m}$ \\
Exit Temperature & $509 \mathrm{~K}$ \\
Exit Velocity & $20 \mathrm{~m} / \mathrm{s}$ \\
Diameter & $0.61 \mathrm{~m}$ \\
Orientation & Vertical \\
Rain Cap & Yes \\
\hline
\end{tabular}

a. Exit velocity for stacks with rain caps is set to $0.001 \mathrm{~m} / \mathrm{s}$ in AERMOD per Idaho DEQ modeling guidelines (DEQ 2013).

Boiler 5 has a rated capacity of 29.3 MMBtu/hr and a design-rated fuel-consumption rate of $209.2 \mathrm{gal} / \mathrm{hr}$ \#2 Diesel. Emission rates were calculated using the design-rated fuel-consumption rate and appropriate emission factors using the following formula:

$$
E R\left(\frac{l b}{h r}\right)=\frac{F R\left(\frac{g a l}{h r}\right) E F\left(\frac{l b}{1000 \text { gal }}\right)}{1000\left(\frac{\text { gal }}{1000 \text { gal }}\right)}
$$

Where

$$
\begin{aligned}
& E R=\text { emission rate } \\
& F R=\text { design rated fuel consumption rate } \\
& E F=\text { emission factor } \\
& H V=\text { heating value of fuel oil }(140,000 \mathrm{Btu} / \mathrm{gal})
\end{aligned}
$$

Emission factors were taken from AP-42 (EPA 2009). The emission factors and emission rates are shown in Table 2. Emission rates were converted from $\mathrm{lb} / \mathrm{hr}$ to $\mathrm{g} / \mathrm{s}$ for input to AERMOD.

Table 2. CAP emission factors and rates.

\begin{tabular}{lccc}
\hline & $\begin{array}{c}\text { Emission Factor } \\
(\mathrm{lb} / 1000 \mathrm{gal})\end{array}$ & $\begin{array}{c}\text { Emission Rate } \\
(\mathrm{lb} / \mathrm{hr})\end{array}$ & $\begin{array}{c}\text { Emission Rate } \\
(\mathrm{g} / \mathrm{s})\end{array}$ \\
\hline $\mathrm{SO}_{2}$ & $0.213^{\mathrm{a}}$ & 0.0445 & 0.00561 \\
$\mathrm{NO}$ & $20^{\mathrm{a}}$ & 4.18 & 0.527 \\
$\mathrm{CO}$ & $5^{\mathrm{a}}$ & 1.05 & 0.132 \\
$\mathrm{PM}-10 / 2.5^{\mathrm{c}}$ & $2.3^{\mathrm{b}, \mathrm{c}}$ & 0.481 & 0.0606 \\
\hline $\mathrm{a}$. & $\mathrm{SO}_{2}, \mathrm{NO}_{\mathrm{x}}, \mathrm{CO}$ emission factor from AP-42 (EPA 2009) Table 1.3-1. \\
b. & $\mathrm{PM}-10$ emission factor from AP-42 (EPA 2009) Table 1.3-2 (Condensable) and 1.3-6. \\
c. & The PM-10 emission factor was also used for PM-2.5.
\end{tabular}


Rev. 08

Title: $\quad$ Evaluation of Air Quality Impacts from Addition of Boiler 5 at Naval Reactors Facility

$\begin{array}{lllll}\text { ECAR No.: } 4264 & \text { Rev. No.: } 1 & \text { Project No.: N/A } & \text { Date: } 10 / 16 / 2018\end{array}$

\section{Building Wake Effects}

Although public receptors are far enough away from NRF that wake effects are likely to be small, wake effects were included to be conservative and to be consistent with the INL sitewide permit modeling (Sondrup 2015). Wake-effect parameters were determined using the EPA Building Profile Input Program with Plume Rise Enhancement (BPIP-PRIME) (EPA 2004c), Version 04274, designed for use with the AERMOD model. BPIP-PRIME was run under the BEEST for Windows platform (BEE-Line Software, Version 9.95).

Wake-effect parameters were obtained by importing an aerial map of NRF buildings and structures into the BEEST program. The map was generated using the INL iMAP application (https://maps.inl.gov). iMAP is a web-based GIS (geographic information system) application that provides access to map layers and other information about INL facilities and structures. The map was imported into BEEST and positioned (georeferenced) using UTM coordinates. Building, tank, and other structure outlines were created within BEEST.

According to the BPIP user guide (EPA 2004c); structures produce an area of wake effect that extends to a distance of $5 \mathrm{~L}$ where $\mathrm{L}$ is the lesser of the building height or projected building width. Building heights were determined using the measuring tools and the Pictometry ${ }^{\circledR}$ feature in iMAP. Pictometry ${ }^{\circledR}$ is a patented aerial image capture process that produces imagery showing the fronts and sides of buildings and locations on the ground.

Figure 2 shows a three-dimensional (3-D) wireframe building image from the BEEST software. Stack locations are shown in red and labeled. All buildings that could potentially cause a wake effect for each CAP stack source at NRF are shown even though Boiler 5 was the only stack considered. For multitiered structures, the tiers were included, or the entire building height was assumed to be equal to the height of the tallest tier. This was very conservative for some buildings. 
Rev. 08

Title: $\quad$ Evaluation of Air Quality Impacts from Addition of Boiler 5 at Naval Reactors Facility

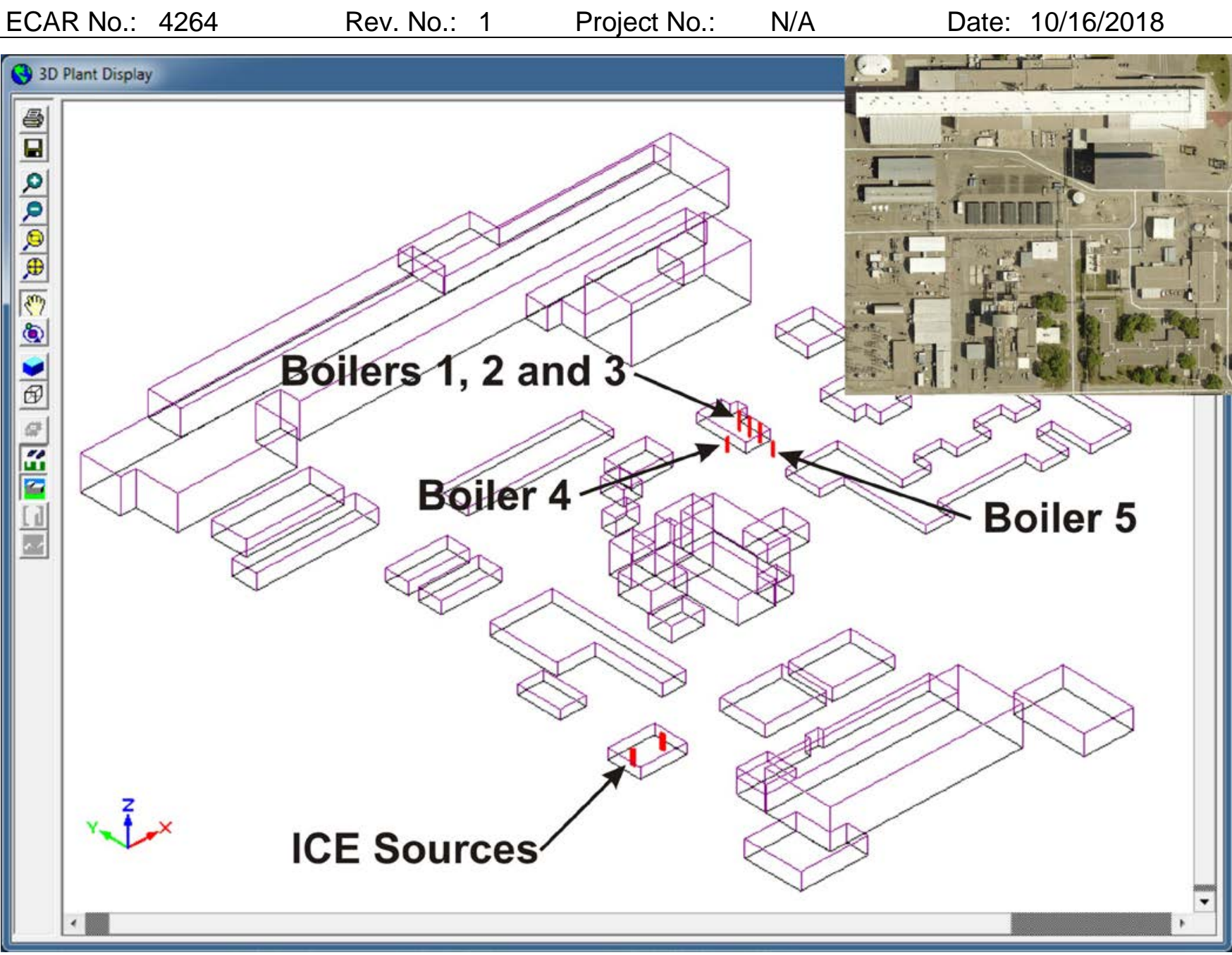

Figure 2. Wireframe image of buildings at NRF used for calculating wake effects. Facility map shown in upper right corner.

\section{Receptor Network}

Receptor locations defined in UTM coordinates (Zone 12) based on datum NAD 83, were provided by Idaho DEQ modeling staff in the file AERMAP723.rcf. This is a text file written in AERMOD format and was used directly in each AERMOD input file. The 1,352 receptor locations shown in Figure 3 are spaced approximately every 500 meters around the INL boundary and along highways that transect the INL. Finer spacing ( 100 meters) was used near facilities where concentrations may be higher (i.e., along Highway 20/26 between AMWTP and CFA, from Highway 20 to the MFC guard gate, and along Highway 33 near the entrance to SMC. Finer spacing was also used in gridded areas around EBR-I $(\sim 40 \mathrm{~m})$ and Atomic City ( 200 meters). All receptors were considered for each pollutant and averaging period for determining maximum impacts. 
Rev. 08

Title: $\quad$ Evaluation of Air Quality Impacts from Addition of Boiler 5 at Naval Reactors Facility

$\begin{array}{llll}\text { ECAR No.: } 4264 & \text { Rev. No.: } 1 & \text { Project No.: N/A } & \text { Date: 10/16/2018 }\end{array}$

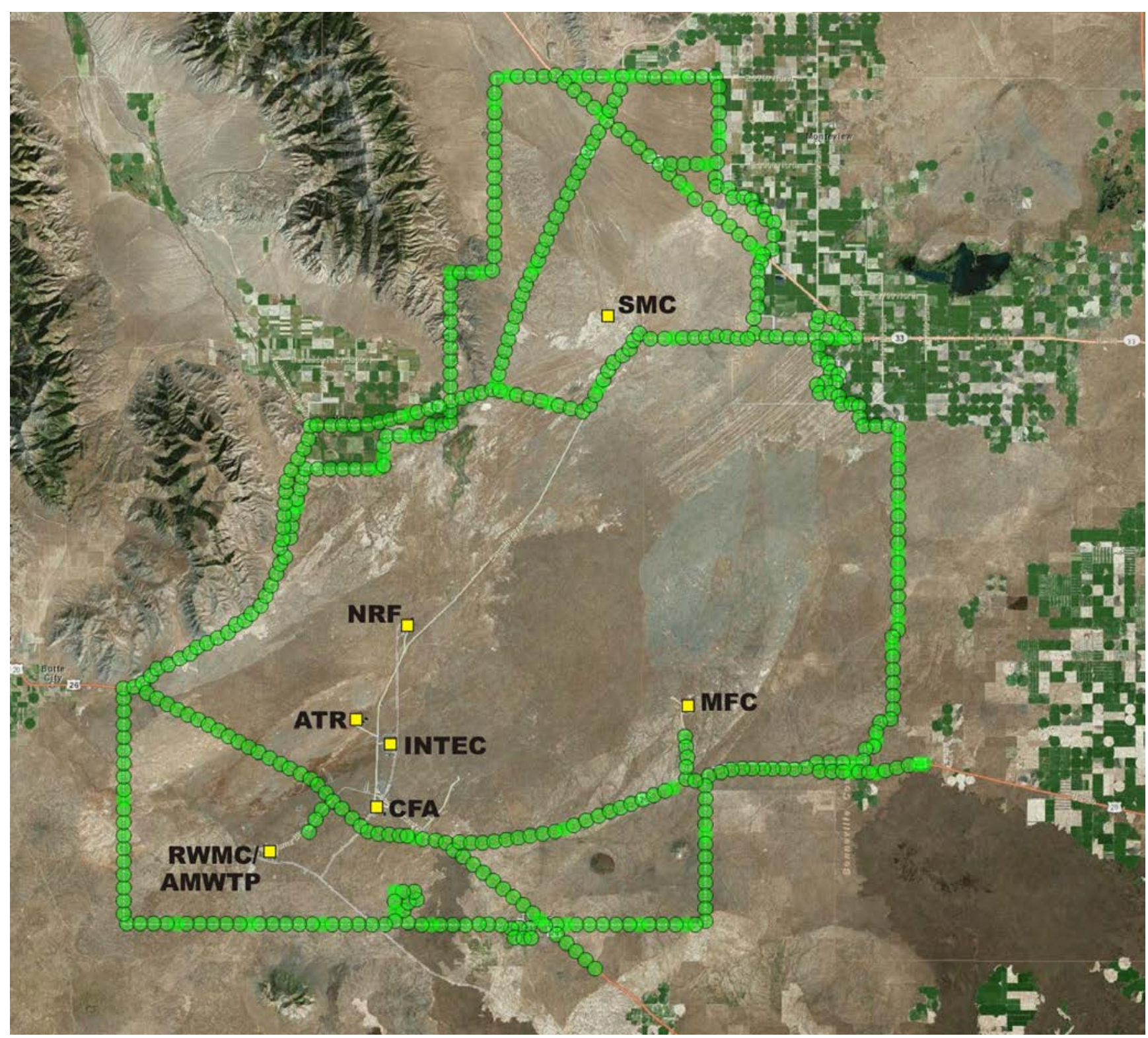

Figure 3. Public receptor locations (green circles) for INL AERMOD modeling. Most circles indicate two or more locations.

\section{RESULTS}

IDAPA 58.01.01 defines a significant contribution as any increase in ambient concentration which would exceed the SCL values in Table 3. This section presents the increases in ambient concentration resulting from only Boiler 5 emissions. The increases are the maximum (overall first highest) values during the 5-year period considered. The concentration results for each CAP and averaging period are presented at the following two locations in Tables 3 and 4 respectively.

1. Table 3 contains maximum concentration increases at any of the 1352 public receptor locations. The table also contains the receptor locations where the maximums occurred (see Figure 4). 
Rev. 08

Title: $\quad$ Evaluation of Air Quality Impacts from Addition of Boiler 5 at Naval Reactors Facility

$\begin{array}{lllll}\text { ECAR No.: } 4264 & \text { Rev. No.: } 1 & \text { Project No.: N/A } & \text { Date: } 10 / 16 / 2018\end{array}$

2. Table 4 contains maximum concentration increases at receptor locations where the maximum concentrations occurred from baseline actual emissions (BAEs) from all significant INL sources considered in the INL Sitewide permit application (DOE-ID 2017). These sources include primarily boilers, emergency generators, certain mobile equipment, and emissions from wasteretrieval and treatment operations. The maximum concentrations from these sources are also shown in the table, along with the receptor locations where they occurred (see Figure 4 for receptor locations).

Table 3 shows that the maximum concentration increases from Boiler 5 emissions at all receptor locations are much less than the SCLs. The largest is the PM-2.5 24-hr concentration at $15.4 \%$ of the $\mathrm{SCL}$. The receptor locations where the maximum increases occur are located north of NRF.

Table 4 shows that the maximum concentration increases from Boiler 5 at the maximum concentration locations from INL BAEs are also much less than SCLs. The largest is the PM-2.5 24-hr concentration at $2.7 \%$ of the SCL. As expected, the concentration increases in Table 4 are less than the values in Table 3 .

Table 3. Maximum concentration increases at any public receptor from Boiler 5 emissions.

\begin{tabular}{|c|c|c|c|c|c|}
\hline Pollutant & $\begin{array}{c}\text { Averaging } \\
\text { Period }\end{array}$ & $\begin{array}{c}\mathrm{SCL} \\
\left(\mu \mathrm{g} / \mathrm{m}^{3}\right)\end{array}$ & $\begin{array}{c}\text { Maximum } \\
\text { Concentration } \\
\text { Increase } \\
\left(\mu \mathrm{g} / \mathrm{m}^{3}\right) \\
\end{array}$ & $\begin{array}{c}\text { Receptor \# of } \\
\text { Maximum } \\
\text { Concentration } \\
\text { Increase } \\
\end{array}$ & $\begin{array}{c}\text { Maximum } \\
\text { Concentration } \\
\text { Increase as \% of } \\
\text { SCL }\end{array}$ \\
\hline \multirow{3}{*}{$\mathrm{SO}_{2}$} & 3-hr & 25 & 0.115 & 651 & $0.5 \%$ \\
\hline & 24-hr & 5 & 0.017 & 131 & $0.3 \%$ \\
\hline & Annual & 1 & 0.00049 & 124 & $0.05 \%$ \\
\hline $\mathrm{NO}^{\mathrm{b}}$ & Annual & 1 & 0.046 & 124 & $4.6 \%$ \\
\hline \multirow{2}{*}{$\mathrm{CO}$} & 1-hr & 2000 & 8.11 & 651 & $0.4 \%$ \\
\hline & 8-hr & 500 & 1.04 & 746 & $0.2 \%$ \\
\hline \multirow{2}{*}{$P M-2.5^{c}$} & 24-hr & 1.2 & 0.185 & 131 & $15.4 \%$ \\
\hline & Annual & 0.3 & 0.0053 & 124 & $1.8 \%$ \\
\hline \multirow{2}{*}{$\mathrm{PM}-10^{\mathrm{c}}$} & 24-hr & 5 & 0.185 & 131 & $3.7 \%$ \\
\hline & Annual & 1 & 0.0053 & 124 & $0.5 \%$ \\
\hline
\end{tabular}

\footnotetext{
a. See Figure 4 for receptor locations.

b. No credit taken for reduction or conversion of $\mathrm{NO}_{\mathrm{x}}$ to $\mathrm{NO}_{2}$.

c. PM-2.5 and PM-10 modeled as total particulate matter and includes condensable PM.
} 
TEM-10200-1

Rev. 08

Title: $\quad$ Evaluation of Air Quality Impacts from Addition of Boiler 5 at Naval Reactors Facility

$\begin{array}{lllll}\text { ECAR No.: } 4264 & \text { Rev. No.: } 1 & \text { Project No.: N/A } & \text { Date: 10/16/2018 }\end{array}$

Table 4. Maximum concentration increases from Boiler 5 emissions at the overall maximum concentration locations from all INL baseline actual emissions.

\begin{tabular}{|c|c|c|c|c|c|}
\hline Pollutant & $\begin{array}{c}\text { Averaging } \\
\text { Period }\end{array}$ & $\begin{array}{c}\mathrm{SCL} \\
\left(\mu \mathrm{g} / \mathrm{m}^{3}\right)\end{array}$ & $\begin{array}{l}\text { Receptor \# of } \\
\text { Maximum } \\
\text { Concentration } \\
\text { from all INL } \\
\text { BAEs }^{\mathrm{a}} \\
\end{array}$ & $\begin{array}{c}\text { Maximum Concentration } \\
\text { Increase from Boiler } 5 \\
\text { emissions at INL BAE } \\
\text { maximum receptor } \\
\text { locations } \\
\left(\mu \mathrm{g} / \mathrm{m}^{3}\right)\end{array}$ & $\begin{array}{c}\text { Maximum } \\
\text { Concentration } \\
\text { Increase from } \\
\text { Boiler } 5 \text { Emissions } \\
\text { as \% of SCL } \\
\end{array}$ \\
\hline \multirow{3}{*}{$\mathrm{SO}_{2}$} & 3-hr & 25 & 563 & 0.0103 & $0.04 \%$ \\
\hline & 24-hr & 5 & 1298 & 0.00301 & $0.06 \%$ \\
\hline & Annual & 1 & 1298 & 0.00014 & $0.01 \%$ \\
\hline $\mathrm{NO}^{\mathrm{b}}$ & Annual & 1 & 1298 & 0.0135 & $1.4 \%$ \\
\hline \multirow{2}{*}{$\mathrm{CO}$} & 1-hr & 2000 & 563 & 0.724 & $0.04 \%$ \\
\hline & 8-hr & 500 & 1298 & 0.180 & $0.04 \%$ \\
\hline \multirow{2}{*}{$\mathrm{PM}-2.5^{\mathrm{c}}$} & 24-hr & 1.2 & 1298 & 0.033 & $2.7 \%$ \\
\hline & Annual & 0.3 & 1298 & 0.0016 & $0.5 \%$ \\
\hline \multirow{2}{*}{ PM-10 } & 24-hr & 5 & 1298 & 0.033 & $0.7 \%$ \\
\hline & Annual & 1 & 1298 & 0.0016 & $0.2 \%$ \\
\hline $\begin{array}{ll}\text { a. } & \text { See Fig } \\
\text { b. } & \text { No cred } \\
\text { c. } & \text { PM-2.5 }\end{array}$ & $\begin{array}{l}\text { for receptor } \\
\text { en for reducti } \\
\text { PM-10 model }\end{array}$ & $\begin{array}{l}\text { ons. } \\
\text { conver } \\
\text { total p }\end{array}$ & $\begin{array}{l}\mathrm{NO}_{x} \text { to } \mathrm{NO}_{2} \text {. } \\
\text { e matter and inc }\end{array}$ & s condensable PM. & \\
\hline
\end{tabular}


TEM-10200-1

Rev. 08

Title: $\quad$ Evaluation of Air Quality Impacts from Addition of Boiler 5 at Naval Reactors Facility

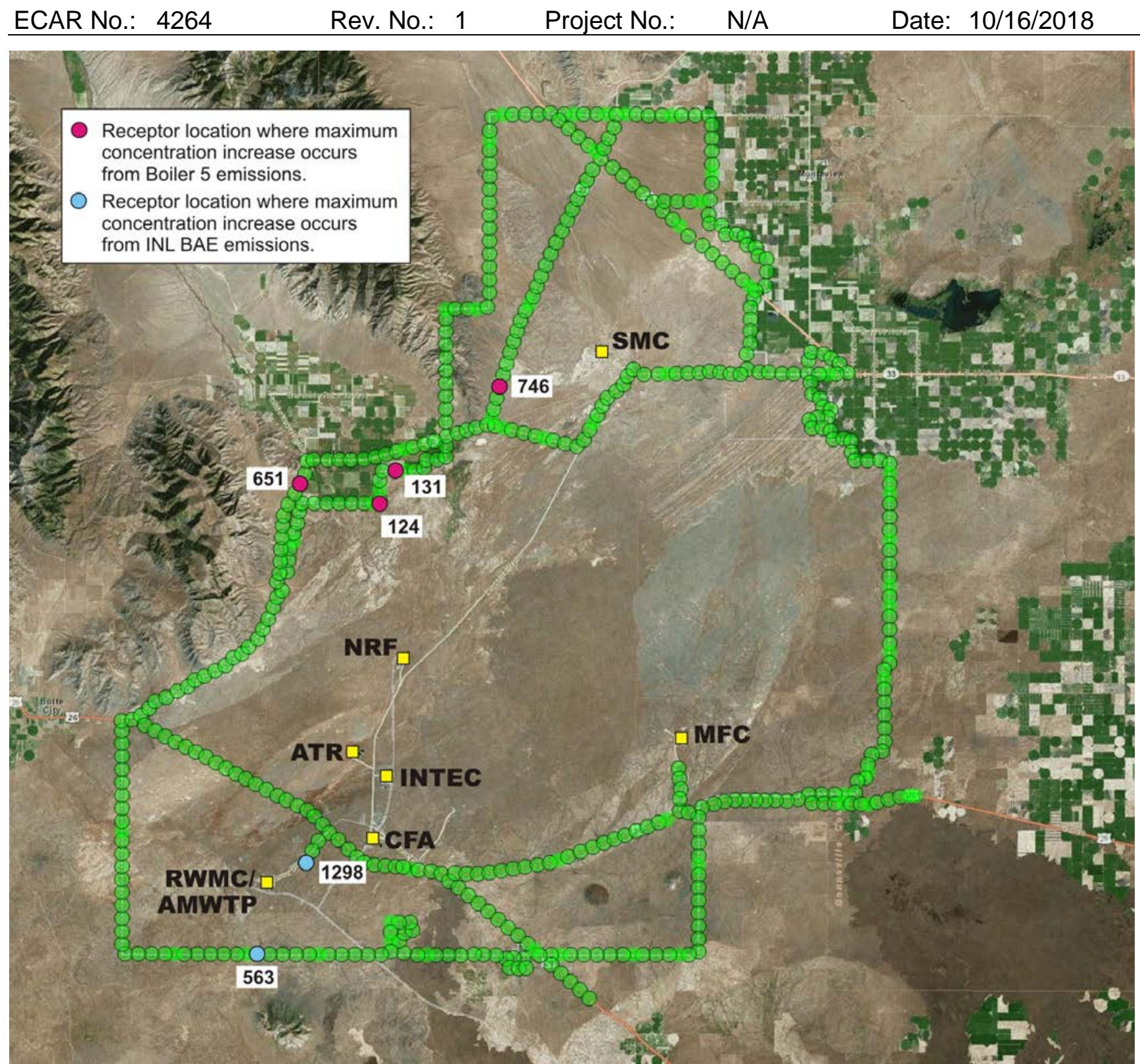

Figure 4. Maximum concentration increase locations for Boiler 5 emissions (red, see Table 3), and INL BAEs (blue, see Table 4).

\section{CONCLUSION}

Maximum increases in CAP concentrations resulting from the addition of NRF Boiler 5 emissions are considerably less than significant contribution levels at all INL public receptor locations. 
Rev. 08

Title: $\quad$ Evaluation of Air Quality Impacts from Addition of Boiler 5 at Naval Reactors Facility

$\begin{array}{lllll}\text { ECAR No.: } 4264 & \text { Rev. No.: } 1 & \text { Project No.: N/A } & \text { Date: } 10 / 16 / 2018\end{array}$

\section{REFERENCES}

DEQ, 2013, "State of Idaho Guideline for Performing Air Quality Impact Analyses," IDEQ Doc ID AQ011 (September 2013), State of Idaho Department of Environmental Quality, Boise Idaho.

DOE-ID, 2017, "Idaho National Laboratory Application for a Synthetic Minor Sitewide Air Quality Permit to Construct with a Facility Emissions Cap Component," DOE/ID-11530, Revision 3, May 2017.

EPA, 2004a, User's Guide for the AMS/EPA Regulatory Model -AERMOD, EPA-454/B-03-001, U.S. EPA Office of Air Quality Planning and Standards, Research Triangle Park, North Carolina, September 2004.

EPA, 2004b, User's Guide for the AERMOD Meteorological Preprocessor (AERMET), EPA-454/B-03002, U.S. EPA Office of Air Quality Planning and Standards, Research Triangle Park, North Carolina.

EPA, 2004c, User's Guide to the Building Profile Input Program, EPA-454/R-93-038, Revised April 21, 2004, U.S. EPA Office of Air Quality Planning and Standards, Research Triangle Park, North Carolina.

EPA, 2009, AP 42, Compilation of Air Pollutant Emission Factors, Volume 1: Stationary Point and Area Sources, Fifth Edition, US EPA.

EPA, 2013, AERSURFACE User's Guide, EPA-454/B-08-001, Revised January 16, 2013, U.S. EPA Office of Air Quality Planning and Standards, Research Triangle Park, North Carolina.

IDAPA 58.01.01, "Idaho Administrative Code, Department of Environmental Quality: Rules for the Control of Air Pollution in Idaho."

R. Brown email to A.J. Sondrup, October 10, 2017, Subject: Remodeling of FEC Permit - Boiler 5 Data.

Sondrup, A.J. and M.A. Verdoorn, 2015, "Modeling Protocol for Evaluation of Air Emissions for the Idaho National Laboratory Site wide Permit to Construct and Facility Emission Cap," INL/MIS15-34065, Idaho National Laboratory.

Sondrup, A.J., 2015, Air Dispersion Modeling for the INL Application for a Synthetic Minor Sitewide Air Quality Permit to Construct with a Facility Emission Cap Component, INL/EXT-15-35241, November 2015. 
TEM-10200-1

$12 / 19 / 17$

ENGINEERING CALCULATIONS AND ANALYSIS

Page $A 1$ of $A 2$

Rev. 08

Title: $\quad$ Evaluation of Air Quality Impacts from Addition of Boiler 5 at Naval Reactors Facility

$\begin{array}{lllll}\text { ECAR No.: } 4264 & \text { Rev. No.: } 1 & \text { Project No.: N/A } & \text { Date: } 10 / 16 / 2018\end{array}$

\section{Appendix A}

\section{Perl Script for Post-processing AERMOD Results}


Rev. 08

Title: $\quad$ Evaluation of Air Quality Impacts from Addition of Boiler 5 at Naval Reactors Facility

ECAR No.: 4264

Rev. No.: 1

Project No::

N/A

Date: $10 / 16 / 2018$

\section{Appendix A \\ Perl Script for Post-processing AERMOD Results}

This appendix contains the listing of the Perl script that is used to post-process the pollutant concentration output files generated by AERMOD using the PLOTFILE command. The script extracts concentrations for each averaging period and writes the results to a text file that is imported into a spreadsheet.

\# Aermodpp.pl

\# Units of source : $\mathrm{g} / \mathrm{s}$

\# Units of conc: $u g / \mathrm{m}^{* *} 3$

if (\$ARGV[0] eq "?")

\{

print "USAGE: Aermodpp.pl [data file] [source name] [pollutant name] NOTE: Default units are g/s for source and ug/m3 for conc \n"; print "If units are not default, then change \$cf variable $\backslash n "$;

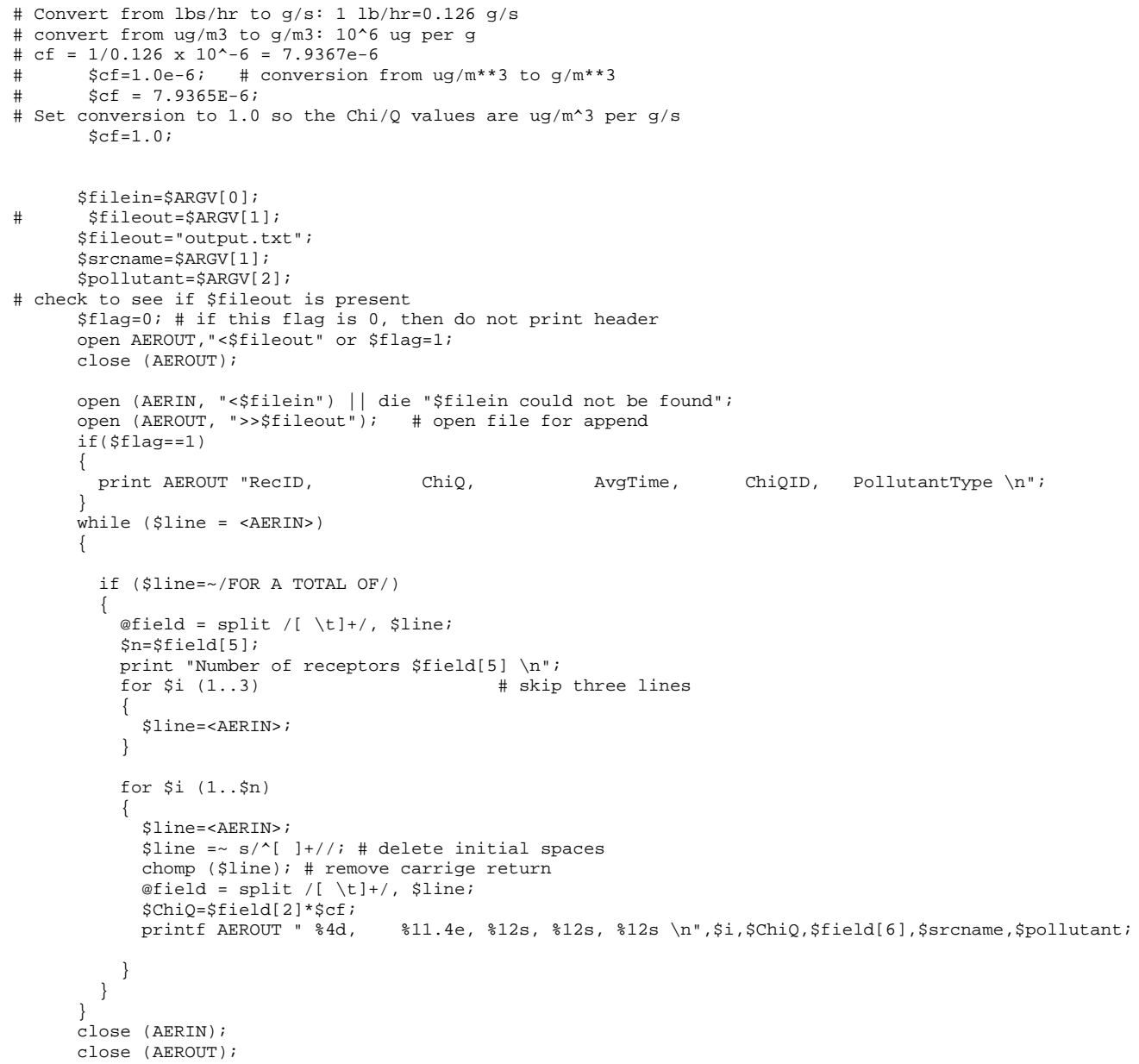

